\title{
IMPACT OF HYDROTHERMAL CONDITIONS ON COMMON BUCKWHEAT (FAGOPYRUM ESCULENTUM MOENCH.) PRODUCTIVITY
}

\author{
ROMANOVSKAJA, D. - RAZUKAS, A. - ASAKAVICIUTE, R. ${ }^{*}$ \\ Voke branch of the Lithuanian research centre for agriculture and forestry \\ (phone: +370-5-2645439; fax: +370-5-2645430) \\ *Corresponding author \\ e-mail: rita.asakaviciute@voke.lzi.lt \\ (phone: +370-5-2645439; fax +370-5-2645430) \\ (Received $18^{\text {th }}$ Aug 2015; accepted $16^{\text {th }}$ Jan 2016)
}

\begin{abstract}
Investigations were conducted during 2004 - 2014 at the Voke Branch of the Lithuanian Research Centre for Agriculture and Forestry. Research purpose - to identify changes in the productivity of buckwheat depending on the variations in hydrothermal conditions during the growing season. Studies have shown that all investigated buckwheat varieties demonstrated high yield variation $(24.3-45.5 \%)$ but somewhat smaller variation of biometric parameters $(6.2-14.7 \%)$. It was found that the trends of increase in variations are associated with reduction of all assessed parameters. This is confirmed by statistically significant correlation between 1000 grains mass and variation coefficient of this parameter $\left(\mathrm{R}^{2}=0.4449 *\right)$. Hydrothermal conditions during the summer season also influenced variation of all parameters. It was found that, due to wetter than optimal hydrothermal conditions in summer, variation of all parameters (except for 1000 grains mass) was lower. Hydrothermal conditions during summer had no effect on the variation of 1000 grains mass. Hydrothermal conditions of separate summer months produced different impact on buckwheat production formation. Rather wet July (if HTC did not exceed 2.5) was favourable and produced a positive effect on buckwheat biometric parameters $\left(R^{2}=0.3475\right.$ and $\left.0.4646^{*}\right)$ and grain yield $\left(\mathrm{R}^{2}=0.4015^{*}\right.$ ). However, at the beginning of vegetation (June) and during grain ripening (August) buckwheat plants require hydrothermal conditions with optimum moisture.
\end{abstract}

Keywords: common buckwheat; yield; climatic conditions

\section{Introduction}

Buckwheat (Fagopyrum esculentum Moench) is an annual herbaceous plant of the Polygonaceae family originating from Central Asia (Sharma and Jana, 2002; Chauhan et al., 2010). It is one of the most important alternative crops, providing raw materials for food and manufacturing industries (Préstamo et al., 2003; Woo et al., 2010; Wronkowska et al., 2010). Buckwheat proteins are characterised by unique amino acid composition, because they comprise large amounts of essential amino acids (Wei et al., 2003; Kim et al., 2004; Krkoškova and Mrazova, 2005). All parts of a buckwheat plant contain large amounts of phenolic compounds, especially rutin (from 0.48 to $4.97 \mathrm{mg} /$ 100 g) (Park et al., 2000; Sharma et al., 2012; Kreft et al., 2003). In addition, it is a melliferous plant: flowers produce 10.9 - $160.2 \mathrm{~kg} \mathrm{ha}^{-1}$ of nectar (Racys and Montviliene, 2005).

Buckwheat is a typical low-input crop that is traditionally cultivated on infertile soils. Because of the short vegetation season, buckwheat grows quickly. These plants could very well consume mineral matter present in the soil, because their roots are able to absorb them from the hard-soluble compounds. They were rarely infected by disease or pests, besides buckwheat plants successfully suppress the weeds. All of it makes buckwheat very suitable for cultivation in organic farming, where no industrial 
fertilizers and plant protection products could be used (Radics and Mikóházi, 2010; Loch and Lazanyi, 2010).

Although buckwheat is a valuable crop, in many countries their areas are not large. In 2010-2011 an average of 2.113 million hectares of buckwheat were grown worldwide; the greater part of these areas are situated in China (34.25\%), Russia (32.43 $\%)$ and Ukraine (11.46 \%) (Popović et al., 2014). Just two decades ago in Lithuania buckwheat crops occupied very small area (4400 hectares), but by 2004 their area has increased by 5 times (up to 21400 ha) (Batulevičiūtè, 2006). Over the past 10 years, in Lithuania buckwheat areas increased by one third (Strakšas and Vaiciukevicius, 2009). The main reason for rather scarce buckwheat cultivation areas is their low productivity compared with other cereals: in Europe it reaches $902 \mathrm{~kg} \mathrm{ha}^{-1}$, in Asia - $890 \mathrm{~kg} \mathrm{ha}^{-1}$, and in America - $1115 \mathrm{~kg} \mathrm{ha}^{-1}$ (Popović et al., 2014 ).

Buckwheat yield is predetermined by the biological properties of these plants and climatic conditions. Buckwheat biology differs from that of other agricultural plants, because buckwheat plants form vegetative and generative organs at the same time. Their flowering is long (about 50 days) and very abundant, but percentage of seed set is very low (Maletić and Jevdjović, 2003). In Belgium the study was carried out with an aim to increase the yield of buckwheat by artificially reducing competition between the flowers and set seed. However, in all cases the seed set reached only $20-30 \%$, and it had only slight effect on the yield (Halbrecq et al., 2005).

Morphological structure of buckwheat flowers allows only cross-pollination. Buckwheat pollination can be performed exclusively by insects, and bees are the main pollinators accounting for 81-95 \% of all insects visiting the buckwheat fields (Björkman, 1995; Racy and Montviliene, 2005). Buckwheat pollination efficiency is related with visits by insects pollinators, and these visits directly depend on the meteorological conditions. Studies performed in Ethiopia show that, with the rising temperature, bees visit flowers more frequently $(\mathrm{r}=0.67, \mathrm{P}=0.01)$, while increasing relative humidity makes these visits less frequent $(\mathrm{r}=-0.59, \mathrm{P}=0.001)$ (Gebremedhn et al., 2014). There is a number of studies about the positive role of bees in buckwheat grain yield formation. It is stated that by way of pollination technological parameters and quality of buckwheat grain improves and the yield increases from 21.7 to 81.0 \% (Sim Choi, 1998; Chen and Tsai, 1994; Aryal et al., 2014; Racys and Montviliene, 2005).

Since buckwheat plants are characterised by specific biological properties, their productivity is closely linked with both visiting insects and the hydrothermal conditions during the growing season. Studies carried out in the Balkans revealed that plant height and grain yield of buckwheat mostly depend on rainfall amount during the growing season. It was noted that the hydrothermal conditions had a significant impact on the duration of pollination period, and moisture deficiency induced more rapid grain ripening (Maletić and Jevdjović, 2003). Czech researchers have found that the hydrothermal conditions during buckwheat flowering and seed set period (July) produced a decisive influence on seed endosperm and shell formation. It is argued that extremely high temperatures and moisture deficiency may terminate seed development (Kalinová et al., 2002). In Japan, the research aiming to determine what meteorological factors were dominant in determining buckwheat productivity was carried out. Model research results showed that the vegetative growth of plants and number of flowers positively correlated with air temperature, but the number of pollinated flowers negatively correlated with daily precipitation amount (Inoue et al., 1998). 
Buckwheat is grown in many parts of the world, where climate is very different. In the future, the buckwheat cultivation areas should be increasing due to increasing demand for healthy food and organic products. Therefore, the knowledge of the causes for changing productivity of these plants due to climate factors is important in order to determine the possibilities of productivity enhancement.

Research purpose - to identify changes in the productivity of buckwheat depending on the variation of hydrothermal conditions during the growing season.

\section{Materials and methods}

\section{Site and soil}

Investigations were conducted in the crop rotation during 2004 - 2014 of the Voke Branch of the Lithuanian Research Centre for Agriculture and Forestry, which is located in Traku Voke $\left(54^{\circ} 63^{\prime} \mathrm{N}, 25^{\circ} 10^{\prime} \mathrm{E}\right)$. The experimental plots were established on sandy loam on carbonaceous fluvial-glacial gravel eluviated soil (IDp), according to FAOUNESCO classification Haplic Luvisols (LVh) (Buivydaite, 2005). Soil agrochemical characteristics: $\mathrm{pH}_{\mathrm{KCl}}-5.2-6.2$, humus $-2.11-2.18 \%$, mobile $\mathrm{P}_{2} \mathrm{O}_{5}-108-152 \mathrm{mg} \mathrm{kg}^{-1}$, mobile $\mathrm{K}_{2} \mathrm{O}-150-165 \mathrm{mg} \mathrm{kg}^{-1}$.

\section{Experimental design and management}

Investigations were carried out in collection nursery of buckwheat selection trial site. Eleven varieties of buckwheat has been tested: buckwheat variety 'VB Vokiai' of Lithuanian (LT) origin (it is a standard variety), other buckwheat varieties of Belarus (BY) origin - 'Volma', 'Smuglianka', 'Anita Belaruskaya', 'Anika', 'Kvietka', 'Canita', 'Zaleika', 'Mara', 'Zniajarka' and 'Belaruskij determinant'. Soil for buckwheat trials was ploughed in the autumn, two times cultivated and harrowed in the spring. Test field area for varieties trials $-1 \mathrm{~m}^{2}$. Planting rate $-3 \mathrm{mln} \mathrm{ha}^{-1}$ of fertile seeds. Each year buckwheat was sown during the third decade of May. Under climatic conditions of Lithuania buckwheat intensively flowered, set and ripened grain during July and August. Grain was harvested during the first decade of September.

\section{Meteorological conditions}

Lithuania is situated in middle latitudes of the temperate zone. A mean annual air temperature of $+6.2{ }^{\circ} \mathrm{C}$, a mean annual precipitation of $661 \mathrm{~mm}$. (Galvonaite et al., 2007). Climate data (monthly temperature and precipitation) for the years $2004-2014$ were obtained from the Lithuanian Hydrometeorological Service. According to the standard climatic rate, in Traku Voke average temperature in summer months is 15.7 $16.9^{\circ} \mathrm{C}$ with an average of $68-78 \mathrm{~mm}$ of rainfall (Table 1).In this area the period of $2004-2014$ was warmer and wetter. Only in June the weather conditions were close to the standard climatic rate. Average temperature in July was by $2{ }^{\circ} \mathrm{C}$, and in August - by $1.3{ }^{\circ} \mathrm{C}$ higher than the average. During the mentioned period, the average precipitation during these two months exceeded the rate by $35-44 \%$. Ratio of precipitation amount and average air temperature helps to better assess the hydrothermal conditions during the growing season of plants, therefore annual meteorological conditions during the period of the experiment are expressed as hydrothermal coefficient (HTC) (Table 2). Thermal and irrigation conditions during the summer season could be described by a widely used Selianinov's hydrothermal coefficient HTC $=\Sigma \mathrm{p} / 0.1 \Sigma \mathrm{t}$, where: $\Sigma \mathrm{p}-$ total 
precipitation $(\mathrm{mm})$ sum during the given period; $\Sigma \mathrm{t}$ - total sum active temperatures $\left({ }^{\circ} \mathrm{C}\right)$ of the same period. If HTC $>1.6$ - the irrigation is excessive, HTC $=1.0 \ldots 1.5-$ optimal irrigation, HTC $=0.9 \ldots 0.8-$ weak drought, $\mathrm{HTC}=0.7 \ldots 0.6-$ moderate drought (arid), HTC $=0.5 \ldots 0.4-$ heavy drought, HTC $<0.4-$ very heavy drought (Dirsė and Taparauskiené, 2010).

Table 1. Meteorological conditions in Traku Voke

\begin{tabular}{l|c|c|c}
\hline \multirow{2}{*}{ Meteorological index } & \multicolumn{3}{c}{ Month } \\
\cline { 2 - 4 } & June & July & August \\
\hline \multirow{3}{*}{ Temperature, ${ }^{\circ} \mathrm{C}$} & Long term average $(1961-1990$ period $)$ \\
Precipitation, $\mathrm{mm}$ & 15.7 & 16.9 & 16.3 \\
& 77 & 78 & 68 \\
Temperature, ${ }^{\circ} \mathrm{C}$ & Average during & $2004-2014$ period & 17.6 \\
Precipitation, $\mathrm{mm}$ & 16.1 & 18.9 & 98 \\
\hline
\end{tabular}

Table 2. Hydrothermal conditions during the summer periods in 2004-2014 Traku Voke, 2004 - 2014 years mean data

\begin{tabular}{l|c|c|c}
\hline \multirow{2}{*}{ Year } & \multicolumn{3}{|c}{ Hydrothermal coefficient (HTC) } \\
\cline { 2 - 4 } & June & July & August \\
\hline 2004 & 2.88 & 0.89 & 1.73 \\
2005 & 1.31 & 1.18 & 3.88 \\
2006 & 0.42 & 0.71 & 2.79 \\
2007 & 1.11 & 3.98 & 0.45 \\
2008 & 1.46 & 1.05 & 1.01 \\
2009 & 2.89 & 1.92 & 1.34 \\
2010 & 2.83 & 3.08 & 1.91 \\
2011 & 0.75 & 2.55 & 1.88 \\
2012 & 2.23 & 1.34 & 1.62 \\
2013 & 1.17 & 1.95 & 1.12 \\
2014 & 1.10 & 1.09 & 2.12 \\
Long term average & 1.63 & 1.49 & 1.35 \\
\hline
\end{tabular}

Meteorological conditions varied among experimental years. Nearly each research year (except for 2008 and 2010) normal and less rainy periods in summer (when HTC <1.5) were interchanging with periods of excess moisture (when HTC > $1.5)$, or vice versa. Based on the standard climatic rate, June is the month of excess moisture (HTC $=1.63)$. However, over the last 11 years this month was particularly rainy only 4 times (in 2004, 2009, 2010 and 2012). During the remaining years of the research hydrothermal conditions in June were of optimal humidity (except for moisture-deficient 2006 and 2011). When in July and August meteorological conditions are consistent with the standard climate norm, the hydrothermal conditions are of optimal humidity (HTC $=1.49-1.35)$. Hydrothermal conditions in July were much wetter than the climate norm during 5 years out of 11 years of the experiment, and in August - during 7 years out of 11. Only in 2008 favourable weather conditions were recorded throughout the summer season. 


\section{Statistical analyses}

The experimental data were statistically processed using analysis of variance and correlation - regression analyses methods employing software Anova, software package Selekcija (Tarakanovas, 2002). The treatment effect was tested by the least significant differences $L S D_{05}$. Significance levels: $* *-\mathrm{p}<0.01 *-\mathrm{p}<0.05$.

\section{Results}

The obtained results showed that over the past 11 years the average grain yield of almost all buckwheat varieties of Belarus origin was higher. Varieties 'Canita', 'Zaleika' and 'Mara' were particularly conspicuous as their grain yield was significantly higher (25.5 - 28.0 \%) than of the standard variety 'VB Vokiai' (Table 3).

Table 3. Buckwheat variety yield and biometric parameters of the collection field trials Traku Voke, 2004 - 2014 years mean data

\begin{tabular}{|c|c|c|c|c|}
\hline Variety & Country & $\begin{array}{c}\text { Grain yield, } \\
\text { t ha }^{-1} \pm S E\end{array}$ & $\begin{array}{l}1000 \text { grains } \\
\text { mass, } g \pm S E\end{array}$ & $\begin{array}{l}\text { Plant height, } \\
\text { cm } \pm \text { SE }\end{array}$ \\
\hline VB Vokiai & LT & $2.71 \pm 0.32$ & $34.2 \pm 1.0$ & $100 \pm 3.6$ \\
\hline Volma & BY & $2.83 \pm 0.41$ & $32.7 * \pm 1.3$ & $105 \pm 4.9$ \\
\hline Smuglianka & BY & $2.80 \pm 0.33$ & $31.8^{*} \pm 1.5$ & $95 \pm 3.5$ \\
\hline Anita Beloruskaya & BY & $2.71 \pm 0.22$ & $31.4 * \pm 1.1$ & $97 \pm 3.9$ \\
\hline Anika & BY & $2.90 \pm 0.22$ & $30.6^{*} \pm 1.2$ & $101 \pm 3.0$ \\
\hline Kvietka & $\mathrm{BY}$ & $3.06 \pm 0.40$ & $31.3 * \pm 1.2$ & $101 \pm 2.9$ \\
\hline Canita & BY & $3.47 * \pm 0.41$ & $31.0 * \pm 1.3$ & $103 \pm 3.7$ \\
\hline Zaleika & BY & $3.40 * \pm 0.38$ & $31.5 * \pm 1.3$ & $104 \pm 2.6$ \\
\hline Mara & BY & $3.44 * \pm 0.38$ & $30.5 * \pm 1.4$ & $104 \pm 2.8$ \\
\hline Zniajarka & BY & $3.09 \pm 0.39$ & $30.8^{*} \pm 1.3$ & $100 \pm 2.0$ \\
\hline Beloruskij determinant & BY & $3.12 \pm 0.33$ & $32.5 * \pm 1.2$ & $98 \pm 3.3$ \\
\hline$L S D_{05}$ & & 0.562 & 1.457 & 5.298 \\
\hline
\end{tabular}

Notes: \pm SE - standard error

However, buckwheat variety 'VB Vokiai' formed larger grains, with 1000 grains mass substantially higher $(4.4-10.8 \%)$ than of other buckwheat varieties. Plants of all tested buckwheat varieties grew to medium height, i.e. height among plants of different varieties ranged from 95 to $105 \mathrm{~cm}$, but no substantial differences were recorded as compared with the plant height of standard variety 'VB Vokiai'.

During the research period, annual variation of yield in all buckwheat varieties was particularly high; coefficient of variation (CV) was $24.3-45.5 \%$ (Fig. 1). However, the variation of biometric parameters was lower. It was determined that, depending on the variety, variation of 1000 grains mass and plant height was low $(\mathrm{CV}<10 \%)$ or medium $(\mathrm{CV}<15 \%)$.

The correlation analysis showed that hydrothermal conditions of the summer season produced no effect only on the variation of 1000 grains mass $\left(\mathrm{R}^{2}=0.0012\right)$ (Figure 2). However, grain yield and plant height variations were changing simultaneously. The downward trends in the coefficient of variation of grain yield and plant height were noted when summer HTC was increasing from 1.2 to 1.8. More humid summer season $(\mathrm{HTC}>1.8)$ increased the variation of grain yield and plant height. 


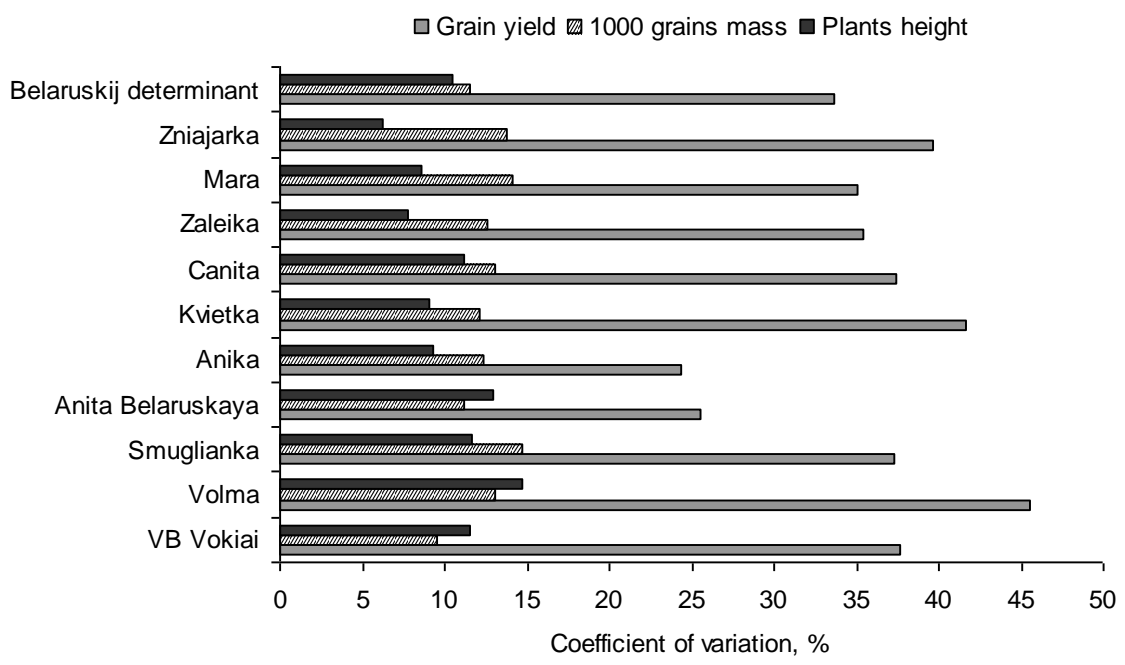

Figure 1. Variation coefficients of the yield, 1000 grains mass, and plant height of buckwheat varieties (CV, \%) (Traku Voke, 2004 - 2014 years mean data)

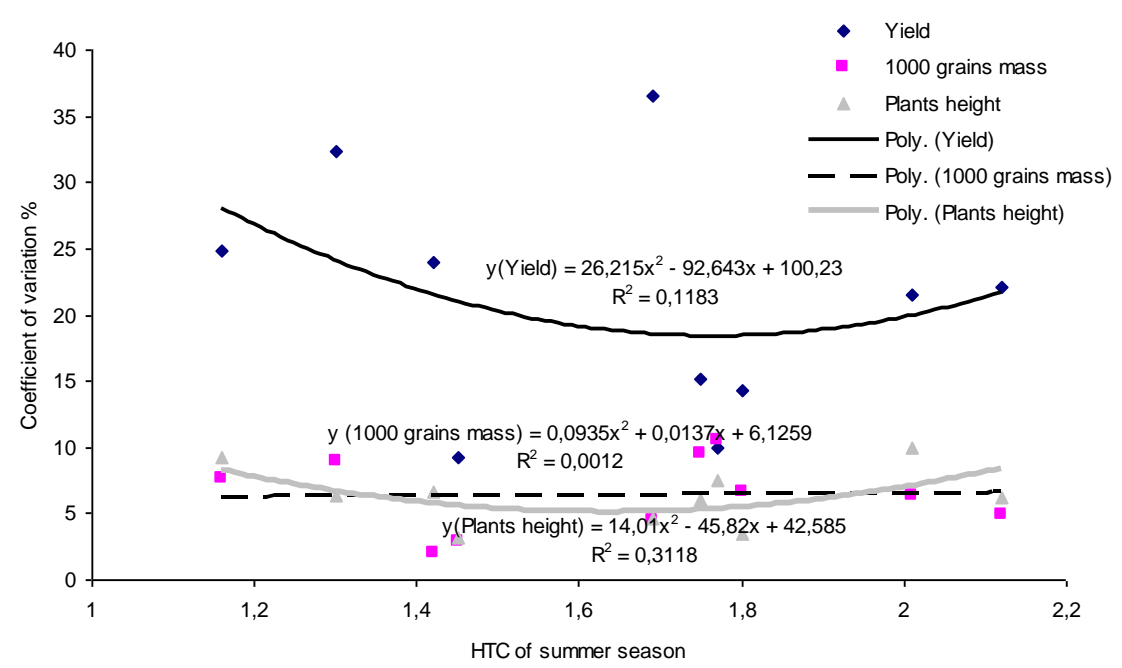

Figure 2. Correlation between hydrothermal conditions (HTC) of the summer period and coefficients of variation (CV, \%) in buckwheat yield, 1000 grains mass and plant height during $2004-2014$

These studies showed that wetter than optimal hydrothermal conditions during the summer season had a positive impact on variation reduction in buckwheat plant height and productivity.

It was revealed that changes of average grain yield and biometric parameters of 11 tested buckwheat varieties were associated with changes in their variations, and it was confirmed by correlation. Statistically significant correlation was established between 1000 grains mass and coefficient of variation of this parameter $\left(\mathrm{R}^{2}=0.4449^{*}\right)$ (Figure $3 b$ ). This shows that in case of higher 1000 grains mass, variation of this parameter among different varieties decreased. Due to decline of grain yield and plant height, upward trends in variations of these parameters were observed. 


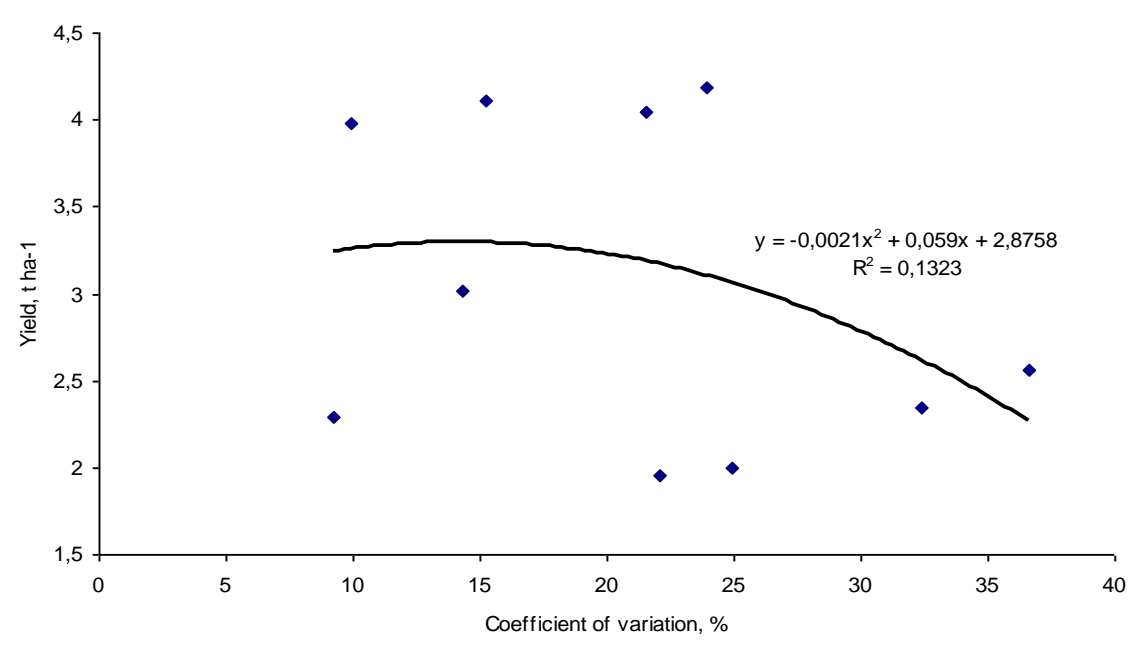

$\mathbf{a}$

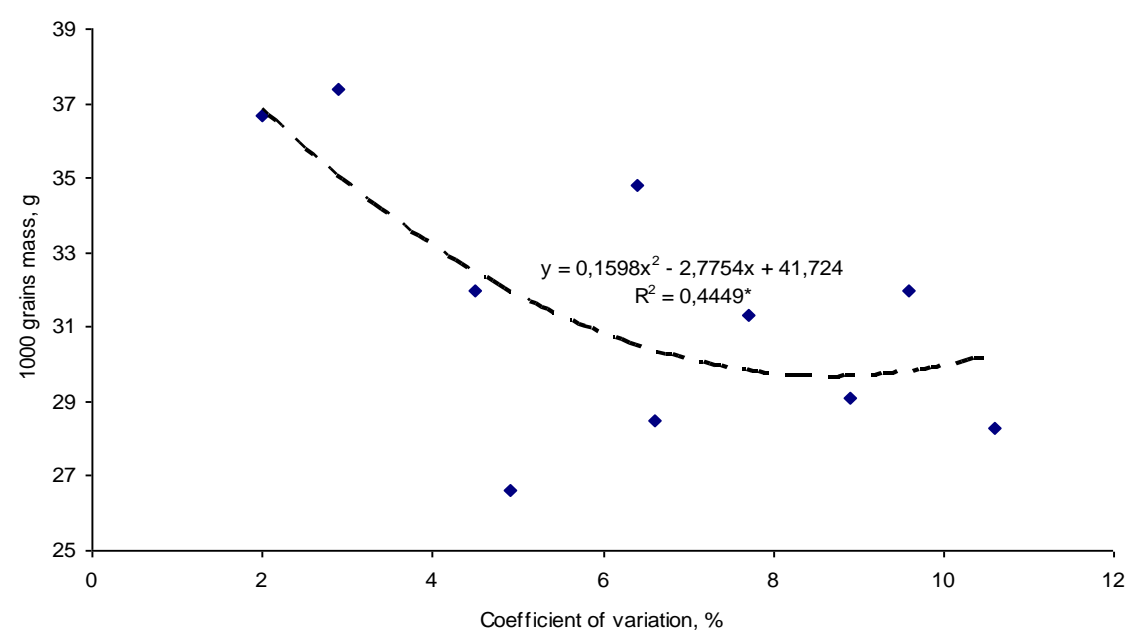

b

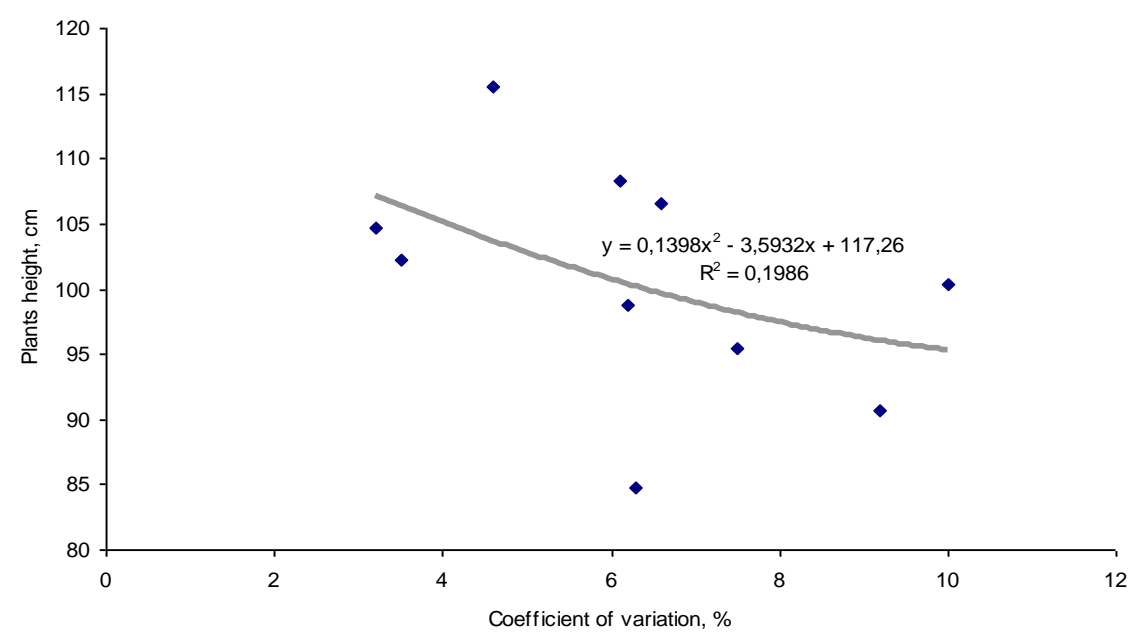

Figure 3. Correlation between the buckwheat grain yield (a), 1000 grains mass (b) and plant height (c) and their coefficients of variation (CV, \%). 
Hydrothermal conditions of each summer month had a different impact on the formation of buckwheat yield. Correlation analysis showed that the lack of moisture in June, when HTC < 1.5, caused decline in buckwheat grain yield (Fig. 4a). Hydrothermal conditions of July affected grain yield stronger than of any other summer month $\left(\mathrm{R}^{2}=0.4015^{*}\right)$. As HTC of July was increasing up to 2.5 , the buckwheat grain yield gradually increased, but further HTC increase caused reduction of the grain yield. During grain ripening period, which coincides with August, excess moisture was unfavourable for buckwheat. Wetter hydrothermal conditions (when HTC > 1.5) resulted in decreased grain yield $\left(R^{2}=0.2645\right)$.

Similar patterns concerning the impact of hydrothermal conditions of July and August were determined for changes of 1000 grains mass (Figure 4b). Although stronger correlations were determined $\left(\mathrm{R}^{2}=0.3475\right.$ and $\mathrm{R}^{2}=0.3636$ respectively), but they were not statistically significant. Very weak correlation with hydrothermal coefficient of June indicates that hydrothermal conditions of this month had no influence on 1000 grains mass.

Based on the correlation analysis, hydrothermal conditions of the whole period until August were influencing the buckwheat plant height. Under hydrothermal conditions of optimum moisture content at the beginning of buckwheat growth (June), the buckwheat plant height was increasing. However, the abundance of rainfall in June and HTC above 2.0 adversely affected the buckwheat plant growth, because at HTC $>2.0$ downward trend in buckwheat plant height was observed (Fig. 4c). The results showed that the buckwheat plant height stronger and statistically significantly correlated $\left(\mathrm{R}^{2}=0.4646^{*}\right)$ with hydrothermal coefficient of July.

The abovementioned results of correlation analyses indicate general trends for all grain varieties. Correlation analysis of hydrothermal conditions in summer and each grain variety yield has been established for higher yields variation during tests. The results have also confirmed the established trends. Positive correlation coefficients show that in June and July high humidity was favorable for most grain varieties yield. In addition, there was commonly moderate and strong correlation $(\mathrm{r}=0.51-0.72)$ between different grain varieties yields and HTC during these months (Table 4).

Table 4. Correlation coefficients between summer hydrothermal conditions $(H T C)$ and tested varieties of buckwheat grain yields

\begin{tabular}{l|c|c|c}
\hline \multirow{2}{*}{\multicolumn{1}{c|}{ Variety }} & \multicolumn{3}{c}{ Coefficient of correlation (r) between grain yield and hydrothermal } \\
& \multicolumn{3}{|c}{ conditions (HTC) } \\
\cline { 2 - 4 } & June & July & August \\
\hline VB Vokiai & 0.40 & 0.40 & $-0.71^{*}$ \\
Volma & 0.37 & $0.68^{*}$ & -0.41 \\
Smuglianka & 0.51 & 0.58 & -0.56 \\
AnitaBeloruskaya & 0.48 & $0.67^{*}$ & -0.42 \\
Anika & 0.58 & 0.42 & -0.42 \\
Kvietka & $0.67^{*}$ & 0.40 & -0.25 \\
Canita & 0.57 & $0.72^{*}$ & $-0.61^{*}$ \\
Zaleika & 0.59 & $0.63^{*}$ & -0.44 \\
Mara & 0.36 & $0.61^{*}$ & -0.46 \\
Zniajarka & 0.53 & 0.55 & -0.44 \\
Beloruskijdeterminant & 0.34 & 0.57 & -0.39 \\
\hline
\end{tabular}



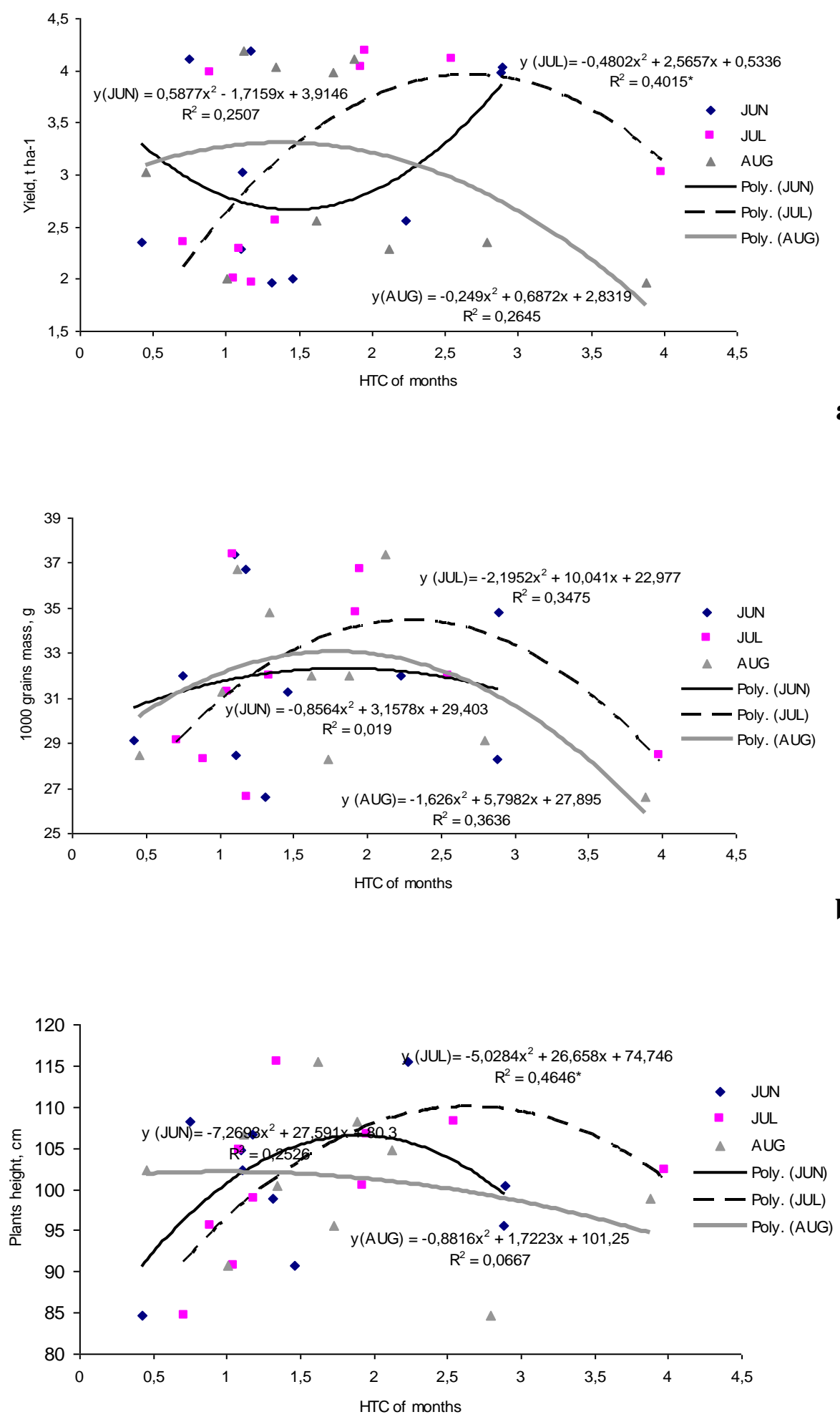

Figure 4. Correlation between hydrothermal conditions (HTC) of summer months and buckwheat grain yield (a), 1000 grains mass (b) and plant height (c) 
Wet hydrothermal conditions in August reduces the yield of all varieties, especially the following: 'VB Vokiai' $\left(\mathrm{r}=-0.71^{*}\right)$, 'Smuglianka' $(\mathrm{r}=-0.56)$ and 'Canita' $(\mathrm{r}=-0.61 *)$.

\section{Discussion}

In Lithuania the buckwheat breeding studies have been carried out since 1999. During the 16-year period the buckwheat variety 'VB Vokiai' was created (Romanovskaja and Razukas, 2006). Until then, buckwheat varieties 'Anita Beloruskaya', 'Smuglianka' and 'Volma', created in Belarus, which is in Eastern Europe in the same climate zone as Lithuania, were widely cultivated. Data analysis of the last decade shows high fluctuations of the buckwheat grain yield in all the tested varieties (coefficient of variation $>20 \%$ ) (Fig. 1). Average yield of buckwheat variety 'VB Vokiai' did not differ or was by $3-4 \%$ lower than of previously popular varieties 'Anita Beloruskaya', 'Smuglianka' and 'Volma' (Table 3). However, during the favourable years $(2000-2001)$ grain yield of variety 'VB Vokiai' was by $7.7-19.1 \%$ higher than of the aforementioned varieties (Almantas, 2002).

In many agricultural systems buckwheat grain yields are low and unstable. It was confirmed by large coefficients of variation determined after statistical evaluation of the results obtained during $2004-2014$ (Fig. 1). Japanese researchers believe that low yield potential is predetermined by allogamy and heterostyly, which make insect pollination indispensable (Ogasahara et al., 1995). Legitimate pollination and the amount of set grain depend on the transfer of suitable pollen on the stigma and favourable meteorological conditions (high temperature - about $20^{\circ} \mathrm{C}$ and high radiation - about $30 \mathrm{cal} \mathrm{cm}^{-2} \mathrm{~h}^{-1}$ ). It was revealed that the highest number of suitable pollen gets on the stigmas when meteorological conditions are favourable $(38.6$ - 39.3), but the numbers are greatly reduced in cool $(25.7-25.8)$ and windy $(17.9-11.9)$ weather (Ogasahara et al., 1995). Small amounts of suitable pollen reaching the stigma or limited activity of pollinators, especially in rainy weather, result in inadequate pollination and low yield potential.

Meteorological conditions of summer months affect not only the process of pollination but the growth of plants as well. In our climate, June is the period of intense buckwheat vegetative growth and biomass formation, therefore wetter hydrothermal conditions (when HTC > 1.5) in June were more favourable that drier conditions and had a positive impact on the productivity of buckwheat (Fig. 4a). Physiologically buckwheat flowering and grain formation take place simultaneously and lasts for about 2.5 months (from late June to mid-September). Hydrothermal conditions of this period may affect the formation of flowers, the pollination process, and thus predetermine the buckwheat yield. The model developed in Japan helped evaluate the influence of various factors on buckwheat. Harvest index (HI) was calculated employing the quantities of formed flowers, pollinated flowers and ripened grain, with regard to buckwheat physiology and ecological factors in the course of different growing seasons (Inoue et al., 1998). It was determined that buckwheat vegetative growth and flower formation positively correlated the mean daily temperature, but negatively correlated with the daily temperature range. Meanwhile the quantity of pollinated flowers negatively correlated with both day length and precipitation of each day (Inoue et al., 1998). It means that high temperature during the day had a negative effect on flower formation, and high rainfall negatively affected flower pollination.

According to the results of the research performed in Lithuania, buckwheat yield strongly correlated with hydrothermal conditions of July $\left(\mathrm{r}=0.83^{* *}\right)$ and August $(\mathrm{r}=$ 
$0.63^{* *}$ ) (Asakavičiūtė et al., 2015). The impact of hydrothermal conditions of this twomonth period on the buckwheat yield amounted to 40 - $69 \%$ of all factors. Our research shows that over the past 10 years the impact of hydrothermal conditions in July on grain yield was higher than of any other summer month $\left(\mathrm{R}^{2}=0.4015^{*}\right)$ (Fig. 4a). It was revealed that wet hydrothermal conditions in July (up to the limit of HTC not exceeding 2.5 ) increased the buckwheat grain yield. In July, hydrothermal conditions corresponding $\mathrm{HTC}=2.5$ could form when rainfall is about $70 \%$ higher than the climate norm. Based on our results and results published in other countries, we can conclude that higher moisture content during the period of intense flowering (July) is essential for buckwheat, and it has a positive effect on the grain yield. Researchers of Serbia and Montenegro state that buckwheat is more suitable for cultivation in wetter regions. Maletić R. and Jevdjović R. (2003) revealed that higher buckwheat grain yield was obtained in the areas with higher amount of rainfall in July (Maletić and Jevdjović, 2003). Still, it should be noted that our research was performed in light textured sandy loam soil (Haplic Luvisol), where rainfall infiltration regime is intense. During the summer season, in sandy loam soil infiltration amounts to $40.5 \%$ of the atmospheric precipitation (Tripolskaja and Pirogovskaja 2013). Average data of the period of 1987 - 2007 show that higher amount of precipitation percolate in July $\left(16.61 \mathrm{~m}^{-2}\right)$ and August $\left(15.21 \mathrm{~m}^{-2}\right)$, less - in June (5.8 1 $\mathrm{m}^{-2}$ ) (Tripolskaja et al., 2014). Therefore, in light textured soils, where in most cases buckwheat is cultivated, even during very wet summers intensive infiltration prevents from excessive moisture. Meanwhile, drier hydrothermal conditions may create unfavourable conditions for buckwheat growth and yield formation. This was confirmed by our data, which showed that the lack of moisture in June caused reduction of buckwheat grain yield (Fig. $4 a$ ). In June, an intensive buckwheat vegetative growth takes place; it requires a larger amount of water to ensure the normal cause of physiological processes and biomass increase. That is why wetter hydrothermal conditions of June are more favourable than drier conditions and produce stronger impact on grain yield formation. Depending on growth stages, buckwheat requires different hydrothermal conditions during the growing season. It was revealed that after germination wet hydrothermal conditions lasting for about $2 / 3$ of the total growing season were agreeable for their productivity. On the contrary, during the grain ripening excessive rainfall produced no positive effect on grain yield. Our research results indicate that at HTC $>1.5$ downward trend in grain yield is observed $\left(\mathrm{R}^{2}=0.2645\right)($ Fig. $4 a)$. So it be said that during the grain ripening period, which coincides with August, optimal moisture hydrothermal conditions ( $\mathrm{HTC}=1.0 \ldots 1.5)$ are essential.

Particular feature of different buckwheat varieties is a grain size, which is expressed evaluating the 1000 grains mass. It is a less variable parameter, since grain size is hereditary. According to the results of breeding studies performed in Lithuania, the heredity of grain size accounted for $47.6 \%$ (Romanovskaja and Razukas, 2007). However, studies have shown that over the past 10 years, 1000 grains mass slightly fluctuated depending on meteorological conditions, but variation of the parameter was low ( $\mathrm{CV}=9.5-14.7 \%$ ) (Fig. 1). In most research variety 'VB Vokiai' was distinguished among other varieties by very large grain (Almantas, 2002; Romanovskaja and Razukas, 2006; Asakaviciute et al., 2015). In the period of this research 1000 grains mass of variety 'VB Vokiai' was $34.2 \mathrm{~g}$, i.e. substantially higher than of other buckwheat varieties $(30.5-$ $32.7 \mathrm{~g}$ ) (Table 3). It should be noted that buckwheat grain size affects technological characteristics and grain yield. It is noted that the fraction of large grain formed higher percentage in the yield of the buckwheat varieties that are characterized by higher 1000 
grains mass (Asakaviciute et al., 2015). Czech researchers have found that with increasing 1000 grains mass, the fraction of large (about $4.5 \mathrm{~mm})$ grain $(\mathrm{r}=0: 45)$ and grain yield $(\mathrm{r}=$ $0.825^{* *}$ ) also increased (Kalinová et al., 2002).

Our research results show that biometric parameters of buckwheat also depended on the hydrothermal conditions, but the impact of hydrothermal conditions during separate months of growing season on the 1000 grains mass and on plant height was different. It was revealed that hydrothermal conditions in June had no effect on 1000 grains mass $\left(\mathrm{R}^{2}=0.019\right)$ (Fig. 4 B), while hydrothermal conditions in August did not affect the height of plants $\left(\mathrm{R}^{2}=0.0667\right)($ Fig. $4 c)$. Although buckwheat plants are intensively growing in the first half of vegetation, but hydrothermal conditions in June $\left(\mathrm{R}^{2}=\right.$ $0.2526)$ had less impact on their height than hydrothermal conditions in July $\left(\mathrm{R}^{2}=\right.$ 0.4646*) (Fig. 4 C). Meanwhile relatively wet hydrothermal conditions in July (if HTC did not exceed 2.5) were favourable and had a positive influence on buckwheat biometric characteristics and grain yield.

\section{Conclusions}

Over the research period (2004 - 2014) all tested buckwheat varieties were characterised by high yield variation $(\mathrm{CV}=24.3-45.5 \%)$, but lower variation of biometric parameters $(\mathrm{CV}=6.2-14.7 \%)$. It was revealed that upward trends in variations are decline of all parameters assess during the study. It is particularly justified by statistically significant correlation between 1000 grains mass and variation coefficient of this biometric parameter $\left(\mathrm{R}^{2}=0.4449^{*}\right)$. Hydrothermal conditions during the summer season or during separate summer months also influenced variation of all parameters. The research results show that wetter than optimal hydrothermal conditions in summer resulted in lower variation of all parameters (except for 1000 grains mass). However, hydrothermal conditions of the summer season did not affect the variation of 1000 grains mass. Hydrothermal conditions of separate summer months had a different impact on the formation of buckwheat yield. Rather wet hydrothermal conditions in July (if HTC did not exceed 2.5) were favourable and produced a positive influence on biometric parameters of buckwheat $\left(R^{2}=0.3475\right.$ and $\left.0.4646^{*}\right)$ and grain yield $\left(R^{2}=0.4015^{*}\right)$. Still, at the beginning of vegetation (June) and the period of grain ripening (August) buckwheat plants require hydrothermal conditions of optimum moisture $(\mathrm{HTC}=1.0 \ldots 1.5)$.

Acknowledgements. Research results were obtained through a long-term research program "Genetics and purposeful change of genotypes of agricultural and forest plants" implemented by Lithuanian Research Centre for Agriculture and Forestry.

\section{REFERENCES}

[1] Almantas, G. (2002): Creation and evaluation of buckwheat initial breeding material. Agriculture 78(2): $211-217$.

[2] Aryal, L.N., Thapa, R.B., Tiwari, S., Chaudhary, N.K. (2014): Effect of insect pollination on growth and yield of buckwheat (Fagopyrum esculentum Moench.) in Chitwan, Nepal. - International Journal of Research 1(4): 957-964.

[3] Asakaviciute, R., Romanovskaja, D., Maknickiene, Z., Razukas A. (2015): Breeding and Productivity Aspects of Narrow-leaved Lupine and Buckwheat in Lithuania. - Weber Agricultural Research \& Management 1 (1): 81-86. 
[4] Batulevičiūtè, L. (2006): Development and perspectives of buckwheat growing in Southeastern Lithuania. - Agricultural Sciences 73(26): 26-34 (in Lithuanian).

[5] Björkman, T. (1995): The Role of Honey Bees (Hymenoptera: Apidae) in the Pollination of Buckwheat in Eastern North America. - Journal of Economic Entomology 88: 17391745.

[6] Buivydaite, V.V. (2005): Soil Survey and Available Soil Data in Lithuania. - ESB-RR9: 211-223.

[7] Chauhan, R.S., Gupta, N., Sharma, S.K., Rana, J.C., Sharma, T.R., Jana, S. (2010): Genetic and Genome Resources in Buckwheat - Present Status and Future Perspectives. The European Journal of Plant Science and Biotechnology, pp. 33-34.

[8] Chen, C.T., Tsai, M.L. (1994): Effect of honey bee pollination on production of buckwheat, var Fengtan (Fagopyrum esculentum Moench.). - Chinese Journal of Entomology 14(3): 411-415.

[9] Dirse, A., Taparauskiené, L. (2010): Humidity fluctuations in plant vegetation periods and a comparison of its assessment methods. - Agricultural Sciences 17(1-2): 9-17 (in Lithuania).

[10] Galvonaite, A., Misiuniene, M., Valiukas, D., Buitkuviené, M.S. (2007): Lithuanian climate. Vilnius, pp: 207 (in Lithuanian).

[11] Gebremedhn, H., Tadesse, A., Belay, T. (2014): Relating climatic factors to foraging behavior of honeybees (Apis mellifera) during blooming periodo f Guizotia abyssinica (L.F.). - Livestock Research for Rural Development 26(4), pp: 60.

[12] Halbrecq, B., Romedenne, P., Ledent, J.F. (2005): Evolution of flowering, ripening and seed set in buckwheat (Fagopyrum esculentum Moench): quantitative anglysis. European Journal of Agronomy 23(3): 209-224.

[13] Inoue, N., Hagiwara, M. Kim, H.Y., Matano, T.A. (1998): preliminary study for modeling seed production in common buckwheat. - Fagopyrum 15: 35 - 41.

[14] Kalinová, J., Moudrý, J., Čurn, V. (2002): Technological quality of common buckwheat (Fagopyrum esculentum Moench.). - Rostlinna vyroba 48(6): 279-284.

[15] Kim, S.L., Kim, S.K., Park, C.H. (2004): Introduction and nutritional evaluation of buckwheat sprouts as a new vegetable. - Food Research International 37(4): 319-327.

[16] Kreft, I., Fabjan, N., Germ, M. (2003): Rutin in buckwheat - Protection of plants and its importance for the production of functional food. - Fagopyrum 20: 7-11.

[17] Krkoškova, B., Mrazova, Z. (2005): Prophylactic components of buckwheat. - Food Research International 38(5): 561-568.

[18] Loch, J., Lazanyi, J. (2010): Soil Nutrient Content in Buckwheat Production. - The European Journal of Plant Science and Biotechnology: 93-97.

[19] Maletić, R., Jevdjović, R. (2003): The influence of meteorological conditions on major quantitative and qulitative traits of buckwheat (Fagopyrum esculentum Moench.). Journal of Agricultural Sciences 48(1): 11-19.

[20] Ogasahara, S., Kaji, C., Hagiwara, M., Matano, T. (1995): Pollination of Common Buckwheat (Fagopyrum esculentum Moench) as Influenced by Meteorological Conditions. - Current Advances in Buckwheat Research: 475-481.

[21] Park, C.H., Kim, Y.B., Choi, Y.S., Heo, K., Kim, S.L., Lee, K.C., Chang, K.J., Lee, H.B. (2000): Rutin content in food products processed from groats, leaves, and flowers of buckwheat. - Fagopyrum 17: 63-66.

[22] Popović, V., Sikora, V., Berenji, J., Filipović, V., Dalijanović, Z., Ikanović, J., Dončić, D. (2014): Analysis of buckwheat production in the world and Serbia. - Economics of Agriculture 61(1): 53-62.

[23] Préstamo, G., Pedrazuela, A., Peñas, E., Lasunción, M.A., Arroyo, G. (2003): Role of buckwheat diet on rats as prebiotic and healthy food. - Nutrition Research 23(6): 803814.

[24] Racys, J., Montviliene, R. (2005): Effect of bees-pollinators in buckwheat (Fagopyrum esculentum Moench.) crops. - Journal of Apicultural Science 49(1): 47-51. 
[25] Radics, L., Mikóházi, D. (2010): Principles of Common Buckwheat Production. - The European Journal of Plant Science and Biotechnology: 57-63.

[26] Romanovskaja, D., Ražukas, A. (2006): Buckwheat ((Fagopyrum esculentum) breeding in Lithuania. Agricultural Sciences 1: 31-38 (in Lithuanian).

[27] Romanovskaja, D., Ražukas, A. (2007): Inheritance testing of valuable agronomių traits of buckwheat hybrids in the process of breeding work. - Zemdirbysté-Agriculture 94(4): 62-70 (in Lithuanian).

[28] Sharma, T., Jana, S. (2002): Species relationships in Fagopyrum revealed by PCR-based DNA fingerprinting. - Theoretical and Applied Genetics 105(2-3): 306-312.

[29] Sharma, P., Ghimeray, A.K., Gurung, A., Jin, C.W., Rho, H.S., Cho, D.H. (2012): Phenoloc contents, antioxidant and a-glucosidase inhibition properties of Nepalese strain buckwheat vegetables. - African Journal of Biotechnology 11(1): 184-190.

[30] Sim, Y.G., Choi, Y.E. (1998): Effect of honey bee pollination on production of buckwheat, var Fengtan (Fagopyrum esculentum Moench). - Korean Journal of Apiculture 13(2): 61-68.

[31] Straksas, A., Vaiciukevicius, E. (2009): Research on Biometric Indicators and Aerodynamic Characteristics of Buckwheat Plants and Seeds. - Agricultural Sciences 83(36): 92-97 (in Lithuanian).

[32] Tarakanovas, P. (2002): Data transformation of biological experiments using a computer program ANOVA. - Zemdirbyste-Agriculture 77: 170-180.

[33] Tripolskaja, L., Pirogovskaja, G. (2013): Impact of climate variability in Lithuania and Belarus on atmospheric precipitation infiltration: lysimetric study. - ZemdirbysteAgriculture 100(4): 369-376.

[34] Tripolskaja, L., Verbylienė, I., Razukas, A., Baksienė, E., Sidlauskas, G. (2014) Changes in cation migration in Luvisol resulting from the application of different forms of mineral fertilizers. - Journal of Food, Agriculture and Environment 12 (2): 701-705.

[35] Wei, Y.M., Hu, X.Z., Zhang, G.Q., Ouyang, S.H. (2003): Studies on the amino acid and mineral content of buckwheat protein fractions. - Nahrung. 47(2):114-6.

[36] Wronkowska, M., Soral-Smietana, M., Krupa-Kozak, U. (2010): Buckwheat, as a Food Component of a High Nutritional Value, Used in the Prophylaxis of Gastrointestinal Disseas. - The European Journal of Plant Science and Biotechnology: 64-70.

[37] Woo, S.H., Kamal, A.H. M., Tatsuro, S., Campbell, C.G., Adachi, T., Yun, Y.H., Chung, K.Y., Choi, J.S. (2010): Buckwheat (Fagopyrum esculentum Moench.): Concepts, Prospects and Potential. - The European Journal of Plant Science and Biotechnology: 1-16. 